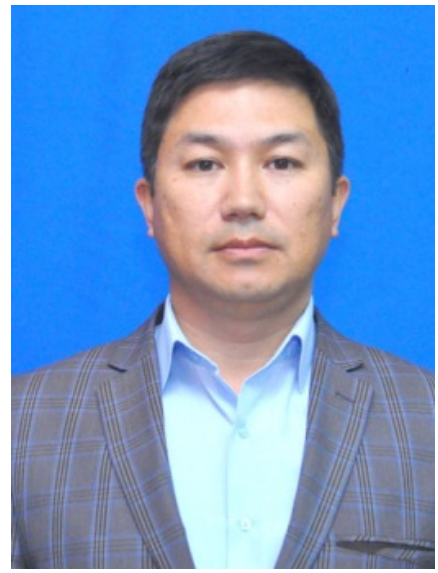

Мирлан Муктарович Дылдаев, канд. геогр. наук, декан факультета

экологии и менеджмента Бишкекского государственного университета им. К. Карасаева, Бишкек, Кыргызская Республика dyldaev@mail.ru

\title{
DOI 10.31554/978-5-7925-0571-1-2019-1-40-44
}

\section{ОСОБЕННОСТИ ПРОЦЕССОВ УРБАНИЗАЦИИ В КЫРГЫЗСКОЙ РЕСПУБЛИКЕ}

В Кыргызской Республике городское население составляет 36 \%. На территории страны расположено более 31 города, а главная отличительная специфика урбанизации заключается в том, что она проходила в условиях горного территориального размещения. Городские территории, как правило, в основном расположены в долинной и низкогорной зоне республики, за исключением некоторых урбосистем, которые расположены в среднегорной части. В Кыргызской Республике природно-исторические процессы и сложившиеся культурно-традиционные особенности повлияли на формирование специфической формы урбанизации. Она отличается от классического типа сравнительно небольшим историческим отрезком времени - порядка 100-150 лет (исключая древние крепости, мавзолеи и караванные торговые стоянки). Это отличает урбанизацию в республике от мировых процессов урбанизации, непрерывность которых имеет тысячелетнюю историю. В последние двадцать лет темпы урбанизации приобрели стихийный характер, вокруг крупных городов (Бишкек, Ош и др.) выросли так называемые «новостройки», застроенные малоэтажными домами без соответствующей инфраструктуры, что существенно ухудшило санитарно-эпидемиологическую и экологическую ситуацию.

Ключевые слова: агломерация, буферные зоны, высотная поясность, геоурбанистика, демографические процессы, миграция, расселение, урбанизированные зоны. 
Тенденция роста городского населения и разрастания территории городов с каждым годом имеет динамику постоянно роста. Это тенденция все активнее наблюдается в странах с переходной экономикой. По мнению Г. М. Лаппо, одного из ярких представителей географической науки и урбанистки, город - особое, ни с чем несравнимое творение ума и рук человеческих. Это среда жизни всевозрастающего числа людей и место концентрации различных, делающихся все более разнообразными видов деятельности. За городами закрепилось название двигателей прогресса. В них рождается и из них распространяется новое. Это творческие лаборатории, духовные мастерские человечества. Классическая география городов как одно из важнейших научных направлений - зародилась в нашей стране еще в 30-е гг. [1987, с. 46].

Другой аспект урбанизации - так называемая «экологическая тень», т.е., использование большого количества природных ресурсов и сырья для поддержания жизнедеятельности города, которое также идет по нарастающей тенденции.

Все это способствует возникновению целого ряда социальноэкономических проблем, связанных с процессами роста городов и увеличением численности населения. При том, что сам процесс урбанизации, который кажется позитивным, по мнению многих аналитиков, порождает бесчисленное множество социальноэкономических и экологических проблем.

Основным стержнем современной структуры и пространственного развития урбанизации в республике явилось формирование городских территорий в условиях масштабной индустриализации и переноса оборонных предприятий. В то же время сложность социальноэкономических преобразований в период независимости привела к диспропорциям в формировании городских населенных пунктов в целом по республике и также к «ложной урбанизации», которая особо ощущается в окрестностях таких крупных городов, как Бишкек и Ош.

В Кыргызской Республике формируется своеобразный горный тип урбанизации с присущими ей элементами. Этот тип, включающий особенности классической, «традиционной» урбанизации, а также формы расселения, которые свойственны горному рельефу или горному типу урбанизации нами именуется как «Горный тип урбанизации MU (Mountain Urbanization)». 
По своей природе урбанизированные территории республики имеют ряд специфических особенностей, характерных для горных районов: а) городские поселения и в целом населенные пункты формируются в условиях горного рельефа (амплитуда высот над уровнем моря составляет 450-7439 м), самые «верхние» поселения и отдельные села расположены на высоте более 3000 м над ур. м.; б) большинство населенных пунктов размещены в долинно-предгорной части и имеют характер неравномерного размещения (на $15 \%$ территории республики сосредоточено почти 80 \% населенных пунктов).

Таким образом, основываясь на работах географов и градостроителей К. Оторбаева (1988), С. Д. Усенова (1991), Э. К. Азыковой (1988), М. М. Дылдаева (2015), на территории республики можно выделить три типа расселения [Дылдаев 2018]:

I тип - низкогорные районы расселения на высоте до 1400 м над ур. м.;

II тип - среднегорный район расселения (1400-1700 м над ур. м.);

III тип - высокогорный район расселения на высоте более 1700 м.

По высотной поясности: до 1000 м, расположено 41 \% городских территорий; от 1000 до 2000 м - 54\% городских территорий; выше 2000 м один город Нарын (3 \%).

Определяя роль экономического потенциала на примере развития урбанизации в Кыргызской Республике, следует отметить, что после распада плановой экономики в начале 1990-х гг. произошли глубокие системные преобразования в сторону нарушения экономической базы. Это не могло не отразится, конечно, и на развитии процессов урбанизации в целом по республике, что привело к «бесконтрольной хаотичной урбанизации», которая особо ощущается в развитии не только крупных городов, но средних и небольших городских образований в Кыргызской Республике. В результате поток внутренней и внешней миграции нарушил демографический баланс в системе расселения.

Экономические преобразования, с которыми столкнулась Кыргызская Республика (спад экономики, снижение социального уровня граждан), отразились на процессах урбанизации и градостроительстве. Со снижением темпов урбанизации связана и слабая градообразующая база городов, в том числе промышленность, наука и т. д. Многие города в следствие спада производства оказались кризисными в 
экономическом плане, усилился отток квалифицированных кадров в другие регионы или страны ближнего и дальнего зарубежья. Из-за этого городские населенные пункты, бюджеты органов местного самоуправления оказались не обеспечены средствами, позволяющими им полноценно функционировать и развиваться, в том числе полноценно планировать перспективы развития.

Многие виды социальных и культурных услуг в населенных пунктах в том числе в малых городах в период независимости из-за непригодности и разворованности социально-культурных объектов стали недоступными для большей части населения. Появились и резко обострились проблемы с ростом заболеваемости, обеспечением чистой питьевой водой и т. п. В малых городах республики существует реальная опасность вспышек инфекций отдельных заболеваний, которые относятся к социальным - туберкулез, бруцеллез, кишечные инфекции, педикулез и т. п.

Геоэкологическое состояние городов в республике в зависимости от степени влияния различных факторов имеет локальные напряженные проявления. Во многих городах существует реальная экологическая угроза, что требует разработки стратегии экологически устойчивого развития урбанизированной зоны. Системообразующими факторами формирования экологической политики должны быть экономические параметры, обоснованная антропогенная нагрузка на окружающую среду и состояние здоровья населения. В настоящее время формирование природно-экологического каркаса окружающей среды городов во многих случаях идет без учета имеющихся техногенных и природно-стихийных процессов и т. д. Представляется обоснованной необходимость активного включения в экологическую политику государства механизмов частно-государственного партнерства, а общественности - в принятие решений по экологическим вопросам.

Необходима государственная поддержка в развитии регионов и принятии концепции расселения в рамках проводимой административно-территориальной реформы, в обеспечении комплексного планирования и стимулировании экономического, социального развития областей и районов, формировании равномерного каркаса системы расселения и размещения населенных пунктов через развитие малых и средних предприятий и сервисной экономики в городах. В том числе на государственном уровне с привлечением инвесторов ежегодно необходимо вводить новые промышленные объекты в малых городах. 


\section{Литература и источники}

Дылдаев М. М., Садыков С. И., Есеналиева Б. Б. Демографические процессы в условиях горного типа размещения населенных пунктов в Кыргызской Республике // Евразийское научное объединение. - 2018. - № 5 (39). - C. 234-236.

Лаппо Г. М. География городов: учеб. пособие / Г. М. Лаппо. - М.: ВЛАДОС, 1987. -480 c. 